\title{
Spatial and temporal variability of urban fluxes of methane, carbon monoxide and carbon dioxide above London, UK
}

\author{
Carole Helfter ${ }^{1}$, Anja H. Tremper ${ }^{2}$, Christoforos H. Halios ${ }^{3}$, Simone Kotthaus ${ }^{3}$, Alex Bjorkegren ${ }^{4}$, \\ C. Sue B. Grimmond ${ }^{3}$, Janet F. Barlow ${ }^{3}$, and Eiko Nemitz ${ }^{1}$ \\ ${ }^{1}$ Centre for Ecology and Hydrology, Penicuik, EH26 0QB, UK \\ ${ }^{2}$ MRC-PHE Centre for Environment and Health, King's College London, London, SE1 9NH, UK \\ ${ }^{3}$ Department of Meteorology, University of Reading, Earley Gate, P.O. Box 243, Reading, RG6 6BB, UK \\ ${ }^{4}$ King's College London, Strand Campus, London, WC2R 2LS, UK
}

Correspondence to: Carole Helfter (caro2@ceh.ac.uk)

Received: 11 March 2016 - Published in Atmos. Chem. Phys. Discuss.: 30 March 2016

Revised: 18 July 2016 - Accepted: 31 July 2016 - Published: 24 August 2016

\begin{abstract}
We report on more than 3 years of measurements of fluxes of methane $\left(\mathrm{CH}_{4}\right)$, carbon monoxide $(\mathrm{CO})$ and carbon dioxide $\left(\mathrm{CO}_{2}\right)$ taken by eddy-covariance in central London, UK. Mean annual emissions of $\mathrm{CO}_{2}$ in the period 2012-2014 (39.1 $\left.\pm 2.4 \mathrm{ktons} \mathrm{km}^{-2} \mathrm{yr}^{-1}\right)$ and $\mathrm{CO}$ $\left(89 \pm 16\right.$ tons $\mathrm{km}^{-2} \mathrm{yr}^{-1}$ ) were consistent (within 1 and $5 \%$ respectively) with values from the London Atmospheric Emissions Inventory, but measured $\mathrm{CH}_{4}$ emissions ( $72 \pm 3$ tons $\mathrm{km}^{-2} \mathrm{yr}^{-1}$ ) were over two-fold larger than the inventory value. Seasonal variability was large for $\mathrm{CO}$ with a winter to summer reduction of $69 \%$, and monthly fluxes were strongly anti-correlated with mean air temperature. The winter increment in $\mathrm{CO}$ emissions was attributed mainly to vehicle cold starts and reduced fuel combustion efficiency. $\mathrm{CO}_{2}$ fluxes were $33 \%$ higher in winter than in summer and anti-correlated with mean air temperature, albeit to a lesser extent than for CO. This was attributed to an increased demand for natural gas for heating during the winter. $\mathrm{CH}_{4}$ fluxes exhibited moderate seasonality ( $21 \%$ larger in winter), and a spatially variable linear anti-correlation with air temperature. Differences in resident population within the flux footprint explained up to $90 \%$ of the spatial variability of the annual $\mathrm{CO}_{2}$ fluxes and up to $99 \%$ for $\mathrm{CH}_{4}$. Furthermore, we suggest that biogenic sources of $\mathrm{CH}_{4}$, such as wastewater, which is unaccounted for by the atmospheric emissions inventories, make a substantial contribution to the overall budget and that commuting dynamics in and out of central business districts could explain some of the spatial and temporal variability of $\mathrm{CO}_{2}$ and $\mathrm{CH}_{4}$ emissions. To our knowledge,
\end{abstract}

this study is unique given the length of the data sets presented, especially for $\mathrm{CO}$ and $\mathrm{CH}_{4}$ fluxes. This study offers an independent assessment of "bottom-up" emissions inventories and demonstrates that the urban sources of $\mathrm{CO}$ and $\mathrm{CO}_{2}$ are well characterized in London. This is however not the case for $\mathrm{CH}_{4}$ emissions which are heavily underestimated by the inventory approach. Our results and others point to opportunities in the UK and abroad to identify and quantify the "missing" sources of urban methane, revise the methodologies of the emission inventories and devise emission reduction strategies for this potent greenhouse gas.

\section{Introduction}

The use of eddy-covariance (EC) for the measurement of turbulent fluxes of heat and mass has grown steadily over the past 3 decades; recently, there were $>400$ active sites worldwide (Baldocchi, 2008) spanning six continents. The vast majority of existing sites were established to measure biosphere-atmosphere exchanges of carbon dioxide $\left(\mathrm{CO}_{2}\right)$ and heat (Baldocchi et al., 2001). Due to recent technological advances, i.e. the development of new fast response analysers, measurements of eddy-covariance fluxes of other trace gases such as methane $\left(\mathrm{CH}_{4}\right)$ and nitrous oxide $\left(\mathrm{N}_{2} \mathrm{O}\right)$ are gradually being introduced (Crosson, 2008; Fiddler et al., 2009; Peltola et al., 2014). With the negotiation of international agreements to greatly reduce greenhouse gas (GHG) emissions by the end of the 21 st century, there is an ever in- 
creasing need to verify emissions through independent monitoring approaches. Despite $54 \%$ of the worldwide population currently living in cities, a figure which could rise to $66 \%$ by 2050 (United Nations, 2014), and $\mathrm{CO}_{2}$ emissions related to urban activities (total of emissions occurring within and outside (e.g. power plants) a conurbation) estimated to represent $70 \%$ of the global budget (International Energy Agency, 2012), there have been comparatively few urban studies to evaluate reported GHG emissions. At the time of writing, 61 urban flux towers were listed in the FLUXNET Urban Flux Network database, of which 40 were located in temperate areas (Grimmond and Christen, 2012).

At present, most published urban studies have focused on $\mathrm{CO}_{2}$ at timescales ranging from a few months to a few years (e.g. Christen et al., 2011; Helfter et al., 2011; Pawlak et al., 2011; Järvi et al., 2012; Liu et al., 2012). Methane, a potent GHG with a global warming potential 28 times larger than that of $\mathrm{CO}_{2}$ at the 100-year horizon (IPCC, 2013), is receiving increasing attention. Whilst $\mathrm{CO}_{2}$ emissions are very closely linked to fuel consumption, for which robust statistics can be obtained (at least at country level), $\mathrm{CH}_{4}$ originates from a much larger range of sources with complex controls. Methane emissions are commonly estimated in "bottom-up" inventories at the national scale (e.g. for IPCC reporting), but also at the urban scale (e.g. London Atmospheric Emissions Inventory in the UK (LAEI, 2013) and the California Air Resources Board (ARB, 2016) in the USA). A variety of techniques have recently been applied to provide independent top-down estimates of urban $\mathrm{CH}_{4}$ emissions. These include ground-based mass balance approaches (McKain et al., 2015), airborne observations (O'Shea et al., 2014; Cambaliza et al., 2015), Fourier Transform Spectrometry (FTS) (Wunch et al., 2009), isotopic source apportionment studies (e.g. Lowry et al., 2001; Zazzeri et al., 2015) and eddycovariance (Gioli et al., 2012; Pawlak and Fortuniak, 2016).

We report on over 3 years of continuous measurements of fluxes of methane, carbon monoxide and carbon dioxide in the heart of London, UK, the largest European city. This is, to our knowledge, the longest continuous urban record of direct $\mathrm{CH}_{4}$ emission flux measurements. This paper investigates the temporal and spatial emission dynamics of the three pollutants and compares annual budgets with the bottom-up emissions inventory estimates.

\section{Materials and methods}

\subsection{Site description}

Fluxes of carbon monoxide (CO), carbon dioxide $\left(\mathrm{CO}_{2}\right)$ and methane $\left(\mathrm{CH}_{4}\right)$ were measured by eddy-covariance from the rooftop of a $190 \mathrm{~m}$ telecommunication tower (BT tower; located at $51^{\circ} 31^{\prime} 17.4^{\prime \prime} \mathrm{N}, 0^{\circ} 8^{\prime} 20.04^{\prime \prime} \mathrm{W}$; Fig. S1 in the Supplement) in central London, UK. The measurements, which are ongoing at the time of writing, began in September 2011. The period September 2011 to December 2014 is analysed here. The mean building height in a radius of ca. $10 \mathrm{~km}$ from the tower is $8.8 \mathrm{~m} \pm 3.0 \mathrm{~m}$ and typically $5.6 \mathrm{~m} \pm 1.8 \mathrm{~m}$ for suburban areas (for more details on the local topography and turbulent air flow characteristics of the site see Wood et al., 2010; Evans, 2009). The Greater London area, which extends ca. $20 \mathrm{~km}$ in all directions from the BT tower, has a population of 8.6 million (Mayor of London Office, 2015) and population densities in excess of $10^{4}$ inhabitants $\mathrm{km}^{-2}$ in the central boroughs.

\subsection{Instrumentation}

\subsubsection{BT tower site}

The eddy-covariance system used at the BT tower consisted of a 3-D ultrasonic anemometer (R3-50, Gill Instruments), a Picarro cavity ringdown spectrometer (CRDS) model 1301$\mathrm{f}$ for the measurement of $\mathrm{CO}_{2}, \mathrm{CH}_{4}$ and $\mathrm{H}_{2} \mathrm{O}$ mole fractions and an Aerolaser fast CO monitor model AL5002. The anemometer was mounted on top of a lattice tower located on the roof of the BT tower giving an effective measurement height of $190 \mathrm{~m}$ above street level. The two gas analysers were located a few floors below the roof, in an air conditioned room. Air was sampled from ca. $0.3 \mathrm{~m}$ below the anemometer head at $20-25 \mathrm{~L} \mathrm{~min}^{-1}$ using a $45 \mathrm{~m}$ long Teflon tube of OD $9.53 \mathrm{~mm}\left(3 / 8^{\prime \prime}\right)$. The Picarro CRDS was fitted with an inhouse auto-calibration system and calibrated weekly using two different mixtures of $\mathrm{CH}_{4}$ and $\mathrm{CO}_{2}$ in nitrogen (above and below typical ambient concentrations). The anemometer operated at $20 \mathrm{~Hz}$, the $\mathrm{CO}$ analyser at $10 \mathrm{~Hz}$ and the Picarro CRDS, which was set to sample in 3-species mode, operated at $1 \mathrm{~Hz}$. The data were captured by an in-house LabView ${ }^{\text {TM }}$ (National Instruments) data acquisition program which also controlled the auto-calibration system and fluxes were processed offline by a custom LabView program. Although the Picarro 1301-f has the capability to measure concentrations at $10 \mathrm{~Hz}$, at this rate, this older instrument can only measure two of the three compounds $\mathrm{CO}_{2}, \mathrm{CH}_{4}$ and $\mathrm{H}_{2} \mathrm{O}$. Because an internal $\mathrm{H}_{2} \mathrm{O}$ measurement is required for accurate corrections (e.g. Peltola et al., 2014), this would mean that in fast-response mode the instrument can only measure the flux of $\mathrm{CO}_{2}$ or $\mathrm{CH}_{4}$ at any one time. Due to the high measurement height, it was found that a response time of $1 \mathrm{~Hz}$ was sufficient to capture $>70 \%$ of the flux (see below).

In addition to the closed-path system described above, an open-path infrared gas analyser (IRGA model Li7500, LICOR Biosciences) measuring $\mathrm{CO}_{2}$ and $\mathrm{H}_{2} \mathrm{O}$ at $20 \mathrm{~Hz}$ was mounted next to the ultrasonic anemometer on the roof of the BT tower. Both analysers used the same anemometer but data were processed independently with different eddycovariance software packages. In the following text, subscripts “_CP" and "_OP” will respectively denote the closedpath and open-path eddy-covariance systems, and fluxes derived from them, located at the BT tower. 


\subsubsection{King's College London site}

Fluxes of $\mathrm{CO}_{2}$ measured by $\mathrm{EC} \_\mathrm{CP}\left(F_{\mathrm{CO} 2} \mathrm{CP}\right)$ were compared to fluxes measured at an eddy-covariance site at King's College London (KCL; use of subscript "_KCL" to identify this eddy-covariance system in what follows) Strand campus, $2 \mathrm{~km}$ south-east of the BT tower (Fig. S1), where longterm EC measurements have been analysed to study energy exchanges (Kotthaus and Grimmond, 2014a, b), carbon dioxide fluxes (Ward et al., 2015) and the $F_{\mathrm{CO} 2}$ storage term in a dense urban environment (Bjorkegren et al., 2015). Carbon dioxide fluxes are obtained from observations of an openpath Li7500 gas analyser and a CSAT3 sonic anemometer (Campbell Scientific). KCL is within the flux footprint of the BT tower during south-easterly wind directions. Fluxes of $\mathrm{CO}_{2}$ from the KCL site were processed as outlined by Kotthaus and Grimmond (2014a).

For the time August-September 2015, a $\mathrm{CH}_{4}$ sensor (Aerodyne Quantum Cascade Laser (QCL)) was added to the EC system at KCL to also observe $F_{\mathrm{CH} 4}$. No $\mathrm{CO}$ was measured at KCL. The EC_KCL system was operated at the top of a tower situated on the roof of a large building resulting in a measurement height of $50 \mathrm{~m}$ above mean ground level (Ward et al., 2015), i.e. ca. $140 \mathrm{~m}$ lower than for EC_CP. Given that the KCL site is closer to the urban canopy, its source area extends to several hundred metres, while the footprint of the BT tower is much larger, i.e. in the order of kilometres. The QCL measured $\mathrm{CH}_{4}$, nitrous oxide $\left(\mathrm{N}_{2} \mathrm{O}\right)$ and water vapour simultaneously and at $10 \mathrm{~Hz}$. The instrument was housed in an air-conditioned cabinet to minimize temperature fluctuations. Air was sampled ca. $20 \mathrm{~cm}$ below the anemometer head at $20 \mathrm{~L} \mathrm{~min}^{-1}$ through a $25 \mathrm{~m}$ long Teflon tube with outer diameter $1.27 \mathrm{~cm}\left(1 / 2^{\prime \prime}\right)$. The data were logged using an inhouse LabView program and processed offline as outlined in Sect. 2.3.

\subsection{Data processing and filtering}

\section{Half-hourly fluxes}

Half-hourly fluxes were calculated using standard eddycovariance methodology extensively described elsewhere (e.g. Aubinet et al., 2000; Foken et al., 2004; Moncrieff et al., 2004). The quality control procedures and the performance of the eddy-covariance system at the tall tower are presented in Sects. 2.3.1 to 2.3.3.

\section{Monthly and annual emissions}

Monthly emissions were calculated from mean diurnal flux profiles constructed by averaging half-hourly fluxes into 24 nominal hourly bins. Annual emissions were estimated by summing monthly averages. However, the data period September 2012-March 2013 (no ultrasonic anemometer) was gapfilled using available monthly averages obtained over the remaining measurement period. Due to insufficient tem-

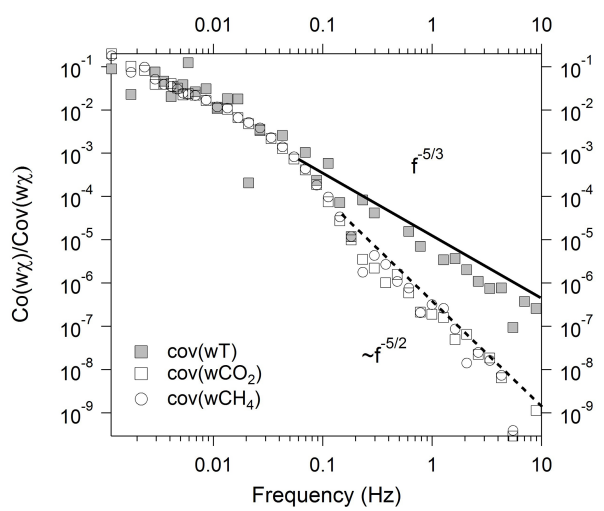

Figure 1. Normalized cospectra of $T$ (sonic temperature), $\mathrm{CO}_{2}$ and $\mathrm{CH}_{4}$ with respect to $w$ (vertical wind component). Each cospectrum is an average of 24 half-hourly cospectra (data period 12 March 2013 07:00-18:00). Regression of spectra for frequencies $>0.1 \mathrm{~Hz}$ marked by solid line for $\mathrm{Co}(\mathrm{w} T)$ and dashed line for both $\mathrm{Co}\left(\mathrm{wCO}_{2}\right)$ and $\mathrm{Co}\left(\mathrm{wCH}_{4}\right)$.

poral coverage, individual annual budgets for 2012-2014 could not be derived for the $\mathrm{CO}$ flux. A composite annual emissions estimate was compiled instead which made use of all available monthly averages of $F_{\mathrm{CO}}$ over the study period September 2011 to December 2014.

\subsubsection{High-frequency attenuation}

Normalized cospectra (" $\mathrm{Co}(x)$ ") of $\mathrm{wCO}_{2}$ and $\mathrm{wCH}_{4}$ measured by the closed-path system were corrected to match those of w $T$ (where $T$ is sonic temperature) to assess highfrequency damping caused by the instrument's limited sampling rate $(1 \mathrm{~Hz})$, internal instrument time response and the long inlet line $(\sim 45 \mathrm{~m})$. $\operatorname{Co}(\mathrm{w} T)$ followed the theoretical $f^{-5 / 3}$ (where $f$ denotes frequency) slope for the inertial sub-range (Foken, 2008) over the entire frequency range (Fig. 1). In contrast, $\mathrm{Co}\left(\mathrm{wCO}_{2}\right)$ and $\mathrm{Co}\left(\mathrm{wCH}_{4}\right)$ diverged from the theoretical slope for frequencies $>0.1 \mathrm{~Hz}$ and followed profiles with slopes of the order of $\sim f^{-5 / 2}$. Relative humidity did not have a significant influence on $\mathrm{Co}\left(\mathrm{wCO}_{2}\right)$ and $\mathrm{Co}\left(\mathrm{wCH}_{4}\right)$ for the two regimes tested $(\mathrm{RH}=52 \%$ and $\mathrm{RH}=80 \%$, data not shown) which suggests that the dominant causes of signal attenuation for our system were the sampling rate and the length of the inlet line. Typical corrections for high-frequency attenuation ranged from 15 to $30 \%$ and based on the co-spectra presented in Fig. 1 it can be inferred that eddies of frequency $<0.1 \mathrm{~Hz}$ carried $>70 \%$ of the flux measured at the $190 \mathrm{~m}$ above-street-level sampling height. The net flux loss resulting from high-frequency attenuation was of the order of $30 \%$ over the entire frequency range. Each half-hourly flux was corrected for high frequency attenuation as part of the offline data processing procedure on a point per point basis. 


\subsubsection{Quality control and filtering}

Half-hourly means were excluded if any of the following quality assurance criteria were not fulfilled.

The number of raw data points per nominal half hour was $<35000$.

The flow rate in the sampling line was $<15 \mathrm{~L} \mathrm{~min}^{-1}$ (theoretical limit of the transitional phase between laminar and turbulent flow for the sampling tube diameter used in this study).

The number of spikes in $u, v, w$ (components of the 3-D wind vector measured by the ultrasonic anemometer) or any of the trace gas mole fractions was $>360$ (i.e. $1 \%$ threshold).

Latent and sensible heat fluxes fell outside the $-250 \mathrm{~W} \mathrm{~m}^{-2}$ to $+800 \mathrm{~W} \mathrm{~m}^{-2}$ range.

The level of turbulence was deemed insufficient for flux measurement (friction velocity, $u_{*}$, threshold of $0.2 \mathrm{~m} \mathrm{~s}^{-1}$ ). This threshold was used for consistency with previous studies carried out at the BT site (Helfter et al., 2011; Langford et al., 2010).

The stationarity test which requires that the difference between the half-hourly flux and the fluxes obtained from $6 \times 5$ min averaging sub-intervals does not exceed $30 \%$ is satisfied (Foken and Wichura, 1996; Foken et al., 2004).

\subsubsection{Comparison between closed-path and open-path systems}

The performance of the closed-path greenhouse gas eddycovariance system located on the 35th floor of the BT tower $\left(\mathrm{EC}_{-} \mathrm{CP}\right)$ was compared to that of the open-path IRGA located on the roof of the tower (EC_OP). After frequency correction, half-hourly $\mathrm{CO}_{2}$ fluxes measured by an openpath Li7500 infrared gas analyser located on the roof of the BT tower $\left(F_{\mathrm{CO} 2}\right.$ OP $)$ were strongly correlated to the fluxes obtained with the closed-path Picarro analyser $\left(F_{\mathrm{CO} 2} \mathrm{CP}\right.$; Fig. 2). Increased scatter in $F_{\mathrm{CO} 2} \mathrm{CP}$, especially during low fluxes, could be due to uncertainties in determining the timelag through maximization of the covariance or also to uncertainties arising from the open-path analyser. The slope of near unity indicates that the high-frequency attenuation of the turbulent flow due to instrument response time, sampling flow rate and length of the sampling line was adequately and systematically corrected for.

$F_{\mathrm{CO} 2 \_\mathrm{CP}}$ clearly varied with friction velocity $\left(u_{*}\right)$ with maximum fluxes observed at $u_{*}$ values around $0.8 \mathrm{~m} \mathrm{~s}^{-1}$, strongly reduced fluxes at low $u_{*}<0.3 \mathrm{~m} \mathrm{~s}^{-1}$ and the indication of reduced values at very high values of $u_{*}$ (Fig. S2). A similar $u_{*}$ dependence was found for the fluxes from the open-path gas analyser (not shown). Near-zero fluxes were recorded by both systems for $u_{*}$ values $<0.1 \mathrm{~m} \mathrm{~s}^{-1}$. For $\mathrm{CO}_{2}$ flux measurements over vegetation, this type of behaviour is usually attributed to a reduction in the transport to the measurement height, resulting in storage of $\mathrm{CO}_{2}$ below that height which may be subject to advection. In the urban en-

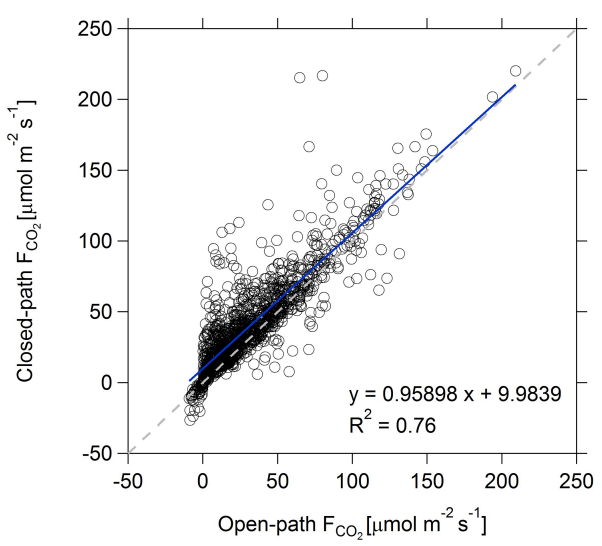

Figure 2. Comparison of half-hourly fluxes of $\mathrm{CO}_{2}$ measured in March, August and October 2013 by a closed-path Picarro G1301-f operating at $1 \mathrm{~Hz}$ following high-frequency loss correction and an open-path Li7500 analyser operating at $20 \mathrm{~Hz}$ at the top of BT tower (sensor height: $190 \mathrm{~m}$ a.g.1.). Dashed line is $1: 1$ line.

vironment, this $u_{*}$ dependence could alternatively arise from an actual correlation between $u_{*}$ and surface emission. Indeed, on average both $u_{*}$ and traffic counts show a minimum at night. However, it is likely that a loss of coupling with street level sources as a result of limited vertical transport occurred in situations of low turbulence. These situations often coincide with stable night-time conditions during which the boundary layer height can approach that of the measurement height (Barlow et al., 2015). In such conditions the measured flux would be an underestimate of the true surface emission due to change in storage in the air column below the measurement height. An explicit treatment of the storage term based on a gradient approach where concentrations and wind speeds are recorded at multiple heights below the EC measurement point could help probe the low $u_{*}$ regime. Such additional measurements were however not available for the BT tower site and we therefore speculate that the observation of venting after onset of turbulence, when the boundary layer grows, would capture at least some if not most of the material stored below the measurement height.

\subsection{Uncertainty analysis}

Random measurement uncertainties were estimated for each half-hourly averaging period using the Finkelstein and Sims (2001) method and subsequently averaged into monthly means. The upper bounds of the random uncertainties associated with the annual emissions estimates were taken as the maximum monthly random uncertainty for each year and trace gas.

Unlike random uncertainties, which arise from instrument noise and representativeness of single-point measurements, systematic errors can be minimized by careful data processing and correction. In particular, successive calibration events were linearly interpolated over time, cancelling out 
errors due to calibration drifts assuming that the drift was linear over time.

So far we have considered the error in the local flux. In addition, there is an uncertainty of how this local flux relates to the emission at the surface. The effects of advection and storage on the flux measurement are difficult to quantify in a heterogeneous environment like a city. However, whilst individual half-hourly flux values may be a poor representation of the momentary emission, we expect the errors to reduce significantly when long-term averages are analysed. The validity of this assumption is explored in more detail in what follows.

\section{Results and discussion}

\subsection{Flux footprint}

For consistency with a previous study (Helfter et al., 2011), the flux footprint for the BT tower measurement site was estimated with the analytical model of Kormann and Meixner (2001) for non-neutral atmospheric stratification, under the simplifying assumptions that fluxes of heat and momentum were homogenous across the footprint. The frequency of observation of $x_{90}$, the distance from the tower where $90 \%$ of the measured fluxes originated from, is shown in Fig. 3 as a function of wind direction and season for the measurement period 2011-2014. The spatial extent of the flux footprint was highly variable over time with recurring seasonal patterns. Typically, $90 \%$ of the flux measured at the BT tower site originated from distances of the order of a few kilometres in spring and summer compared to several tens of kilometres in winter. The flux footprint contains two large parks in the SW (Hyde Park, surface area 142 ha) and NW (Regent's Park, surface area 197 ha), sub-urban residential areas in the $\mathrm{N}$, a mixture of heavily urbanized residential and commercial areas in the $\mathrm{E}$ and $\mathrm{S}$ and a section of the Thames river in the SE.

\subsection{Comparison with flux measurements at a lower height}

\subsubsection{Temporal similarities}

$F_{\mathrm{CO} 2 \text { CP }}$ and $\mathrm{CO}_{2}$ fluxes observed at the $\mathrm{KCL}$ site $\left(F_{\mathrm{CO} 2}\right.$ KCL $)$ exhibited a high temporal correlation (Fig. 4a, b; averaging period 15 September 2011 to 31 December 2013) for diurnal patterns in both winter (defined as DecemberFebruary) and summer (defined as June-August unless otherwise stated). Daily minima occurred at around 03:00 at both sites which is consistent with minimum traffic loads (Fig. 4f, g). Fluxes tended to increase from ca. 05:00-06:00 GMT until late morning and declined steadily from ca. 18:00 at both sites, which is again in agreement with the declining traffic numbers in the evening. Methane fluxes exhibited similar temporal dynamics with the lowest emissions recorded dur-

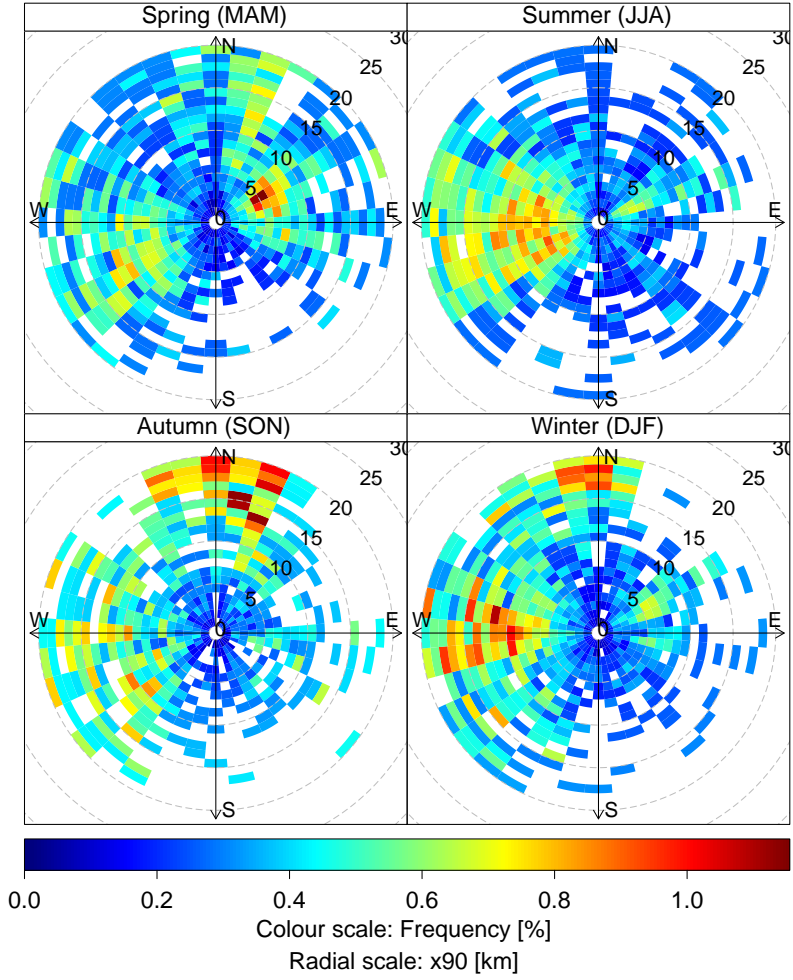

Figure 3. Frequency of occurrence of $x_{90}$ (distance from the tower where $90 \%$ of the measured fluxes originated from) centred at the BT tower as a function of wind direction and season for the period 15 September 2011-31 December 2014. The flux footprint was estimated using an analytical model for non-neutral stratification (Kormann and Meixner, 2001) and the plots were produced using the open-air package for $\mathrm{R}$ (Carslaw and Ropkins, 2012, 2016). Bin dimensions: $10^{\circ}$ (angular scale) $\times 1 \mathrm{~km}$ (radial scale) .

ing the night and a sharp rise between ca. 05:00 and 08:00. A gradual decrease in $F_{\mathrm{CH} 4}$ was observed at both sites following the mid-morning maximum.

In winter, carbon dioxide fluxes started to increase slightly earlier (by about $30 \mathrm{~min}$ on average) at the KCL site. While this time lag was not evident in the summer for $F_{\mathrm{CO} 2}$, methane fluxes started rising later at the elevated measurement point at BT tower even in summer. Boundary layer growth in the morning transition period might explain some of the time delay observed in the carbon fluxes. Mixing height $(\mathrm{MH})$ estimates for several weeks in winter (6 January-11 February 2012) and summer (23 July-17 August 2012) derived from Doppler LIDAR turbulence measurements (Bohnenstengel et al., 2015) at sites close to BT tower (Fig. 4d, e) indicate that, on average, turbulent mixing extended above the BT tower measurement height of $190 \mathrm{~m}$ in both seasons. However, mixing height exhibits great temporal variability depending on the synoptic background conditions; for London it has been found that $\mathrm{MH}$ development depends primarily on the boundary layer winds and stability (Halios and Barlow, 2016) so that these short-term climatol- 

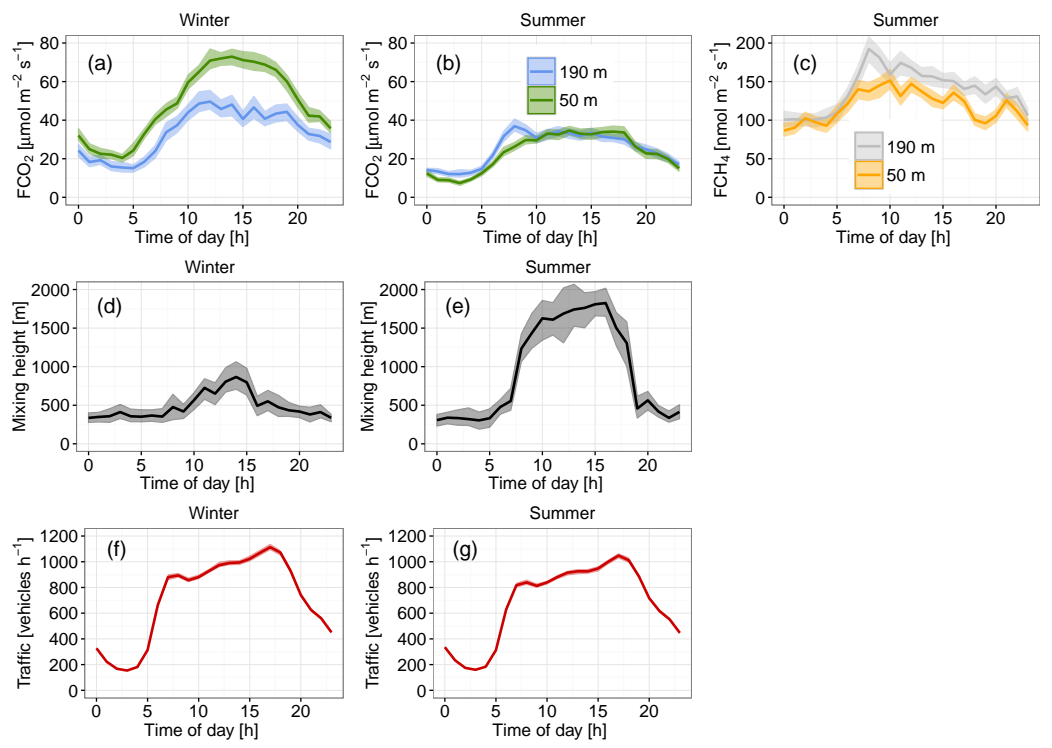

Figure 4. Mean diurnal profiles of $\mathrm{CO}_{2}$ fluxes for (a) winter (DJF), and (b) summer (JJA) for the data period 15 September 2011-31 December 2013; (c) $\mathrm{CH}_{4}$ fluxes in summer observed at the BT tower site (190 m a.g.l.) and the KCL site (50 m a.g.l.) over the period 19 August1 October 2015; mixing height obtained from Doppler LIDAR measurements for (d) winter and (e) summer (Bohnenstengel et al., 2015); road traffic counts (f) winter and (g) summer (average of 246 counting stations distributed throughout the London conurbation; source: Transport for London, 2012 data). The shaded areas represent the $95 \%$ confidence interval.

ogy estimates might not be representative for the full period analysed for the turbulent fluxes.

Growth of the convective layer was rapid in summer and a plateau was typically reached mid-morning which lasted until late afternoon. In agreement with the shorter day-length in winter, growth of the mixing height was slower, collapsing earlier in the evening after the mid-afternoon maximum. Daytime maximum mixing height was about $30 \%$ lower in winter compared to the summer. In both summer and winter, traffic counts rose during the morning transition period, i.e. before the mixing layer started growing considerably (Fig. 4f, g); in the evening, traffic counts began decreasing after the mixing height had reduced in height. Given that the mean temporal evolution of $\mathrm{CO}_{2}$ fluxes observed at both $\mathrm{KCL}$ and $\mathrm{BT}$ tower appeared to be closely linked to the profiles of road traffic, vehicle emissions apparently represent a significant control not only for the local-scale observations at KCL (Ward et al., 2015) but also for fluxes at the elevated BT tower measurement point (Helfter et al., 2011). The slight morning delay in wintertime $F_{\mathrm{CO} 2}$ (Fig. 4a) observed at BT tower might be explained by the efficacy of vertical turbulent transport between street level and the top of the BT tower which has been shown to depend on atmospheric stability. The timescale of upward vertical turbulent transport was estimated to be of the order of $10 \mathrm{~min}$ for near-neutral conditions, increasing to $20-50 \mathrm{~min}$ for stable conditions (Barlow et al., 2011). Low turbulence and prolonged periods of stable atmospheric stratification (Fig. S3) could thus explain the 1$2 \mathrm{~h}$ lag between the timing of the morning increase in traffic counts and fluxes of $\mathrm{CO}_{2}$ at the BT tower during the winter (Fig. 4a). This is consistent with the lag time observed for profiles of potential temperature, and thus upward mixing, measured at the BT tower and a lower-level measurement site close to the BT tower at $18 \mathrm{~m}$ a.g.l. (Barlow et al., 2015). The near-synchronous rise in $\mathrm{CO}_{2}$ and $\mathrm{CH}_{4}$ fluxes observed in summer (summer defined as the months (JJA) in the data period 15 September 2011-31 December 2013 for $F_{\mathrm{CO} 2}$ and the entire period 19 August-1 October 2015 for $F_{\mathrm{CH} 4}$ ) at the two measurement sites (BT and KCL) at different heights is consistent with an earlier onset of turbulent mixing (Fig. 4b, c).

Storage fluxes are difficult to quantify accurately in a heterogeneous environment like a city as this would require vertical profile measurements below the measurement height at several locations within the flux footprint. The analysis presented here therefore relies to some extent on the assumption that, over long periods, positive and negative storage fluxes cancel out and that effects of advection on the stored quantity are negligible. This assumption is further supported by the very small storage fluxes $(<2.5 \%$ of the magnitude of the vertical fluxes) calculated at the KCL site (Bjorkegren et al., 2015), although these would be somewhat larger for the higher measurement height at BT. While the turbulent fluxes observed at the BT tower and KCL show close temporal alignment (Fig. 4a-c) their absolute values can differ considerably (e.g. KCL-to-BT ratios of peak $F_{\mathrm{CO} 2}$ ranged from 1.5 in winter to 0.9 in summer; the summer ratio for $F_{\mathrm{CH} 4}$ was 1.5). 


\subsubsection{Comparison of flux spatial variability at the elevated and roof-top sites}

Both sites are situated in central London where anthropogenic emissions are high due to the elevated density of people and traffic (Ward et al., 2015). While the source area of the BT site includes central business district (CBD) areas with mostly medium-density mid-rise building structures, residential areas as well as large parks, the KCL footprint is dominated by CBD structures with hardly any vegetation (Kotthaus and Grimmond, 2014b). Only the river Thames in its vicinity reduces anthropogenic emission in some parts of the KCL footprint. To evaluate the response of $F_{\mathrm{CO} 2} \mathrm{CP}$ and $F_{\mathrm{CO} 2 \text { KCL }}$ to variations in source area characteristics, the observations were grouped into eight sectors based on the wind direction measured at the $\mathrm{BT}$ tower (Fig. 5). The $\mathrm{CO}_{2}$ fluxes observed at the two sites are linearly correlated for all eight wind sectors but slopes and goodness of fits vary. This is likely due to differences in flux footprints at the two measurement sites, including the extent (a few kilometres at the BT tower and a few hundred metres at KCL; Kotthaus and Grimmond, 2014b) as well as emission source density (a function of surface types). Near 1:1 agreement was found in the dominant SW wind sector (Fig. 5). For other wind directions, differences in local-scale source area between the two EC sites become apparent: while a large green space (Regent's Park) is located to the NW of BT tower, the surface seen by the KCL measurements is least urbanized towards the S and SE of the site (river Thames; note that busy Waterloo bridge towards the SW of KCL acts as a very strong line source of $\mathrm{CO}_{2}$ keeping the fluxes relatively high from this wind direction). In response to the surface cover, $F_{\mathrm{CO} 2} \mathrm{CP}$ exceeds $F_{\mathrm{CO} 2 \text { KCL }}$ in the E, S and SE wind sectors by 20,50 and $70 \%$, respectively, and is lower by $50-70 \%$ in the N, NW and $\mathrm{W}$ sectors with the poorest correlation for the NW sector. The smallest $F_{\mathrm{CO} 2} \mathrm{CP}$ fluxes were observed in the NW sector while $F_{\mathrm{CO} 2 \_ \text {KCL }}$ was highest in sectors $\mathrm{NW}$ and $\mathrm{W}$ where the particularly busy Aldwych junction is located (Kotthaus and Grimmond, 2014a). KCL falls within the footprint of the BT tower site for SE wind direction, but clearly the BT tower measurement sees additional sources due to the larger footprint. The focus was placed on discussing $\mathrm{CO}_{2}$ fluxes in this section because it is the only compound for which we have a second long-term flux record at a lower measurement height. Fluxes of $\mathrm{CH}_{4}$ and $\mathrm{CO}$ measured at the BT tower are presented alongside $\mathrm{CO}_{2}$ in Sects. 3.3-3.5.

\subsection{Diurnal variability of the measured fluxes}

The fluxes of all three gases $\left(F_{\mathrm{CO}}, F_{\mathrm{CO} 2}\right.$ and $\left.F_{\mathrm{CH} 4}\right)$ exhibited well-defined diurnal cycles with minimum emissions during the night, typically from midnight until 05:00 GMT (Fig. 6a-c). Emissions increased sharply from 06:00 reaching a daytime maximum at around 12:00, and then declined steadily until early evening when a local maximum

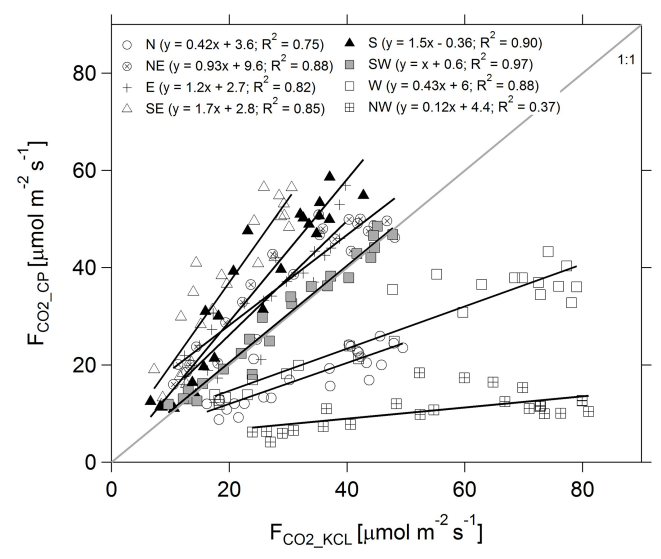

Figure 5. Comparison between average diurnal profiles of $\mathrm{CO}_{2}$ fluxes measured at the BT tower (190 m a.g.1.) and at the KCL site (50 m a.g.1.) in the period 15 September 2011-31 December 2013 , separated into eight wind-direction sectors based on the wind direction observed at BT tower.

was observed at around 18:00-19:00. Mean $F_{\mathrm{CH} 4}$ ranged from 5.7 to $11.0 \mathrm{~kg} \mathrm{~km}^{-2} \mathrm{~h}^{-1}$ (maximum-to-minimum ratio of 1.9), $F_{\mathrm{CO} 2}$ from 1867 to $6635 \mathrm{~kg} \mathrm{~km}^{-2} \mathrm{~h}^{-1}$ (maximum-tominimum ratio 3.5 ) and $F_{\mathrm{CO}}$ from 4.6 to $16.9 \mathrm{~kg} \mathrm{~km}^{-2} \mathrm{~h}^{-1}$ (maximum-to-minimum ratio 3.7 ), demonstrating that the relative dynamic range of $\mathrm{F}_{\mathrm{CH} 4}$ is less than that of the other compounds.

The summertime fluxes of $\mathrm{CH}_{4}$ measured at the $190 \mathrm{~m}$ height did lag slightly behind the fluxes observed at the $50 \mathrm{~m}$ height, but this apparent delay could have been caused by differences in flux footprint between the sites (e.g. the source area of the BT tower fluxes has a much higher fraction of vegetation cover than the KCL footprint) and the fact that the diurnal profiles were obtained for a much shorter time period (August-September 2015). The similarity in $F_{\mathrm{CH} 4}$ temporal dynamics between the two sites supports the idea that the diurnal variations for that gas represent real variability in its source strength rather than an artefact of atmospheric transport as suggested by Gioli et al. (2012) for the Florence (Italy) case study. Indeed, the diurnal variations in $\mathrm{F}_{\mathrm{CH} 4}$ measured at the BT tower were mirrored by strongly suppressed night-time $\mathrm{CH}_{4}$ fluxes observed at a much lower height at the KCL site (Fig. 4c), where the storage error has been demonstrated to be small for $\mathrm{CO}_{2}$ (Bjorkegren et al., 2015). This suggests that fugitive emissions from the natural gas distribution network, which are thought to be the dominant cause of urban $\mathrm{CH}_{4}$ emissions in developed cities, exhibit diurnal variations and/or that other $\mathrm{CH}_{4}$ sources with temporal variations (e.g. fugitive emissions from natural gas appliances) are more significant than estimated by LAEI. This is further supported by $F_{\mathrm{CH} 4}$ being smaller at the weekend than on weekdays (Fig. 6g). 

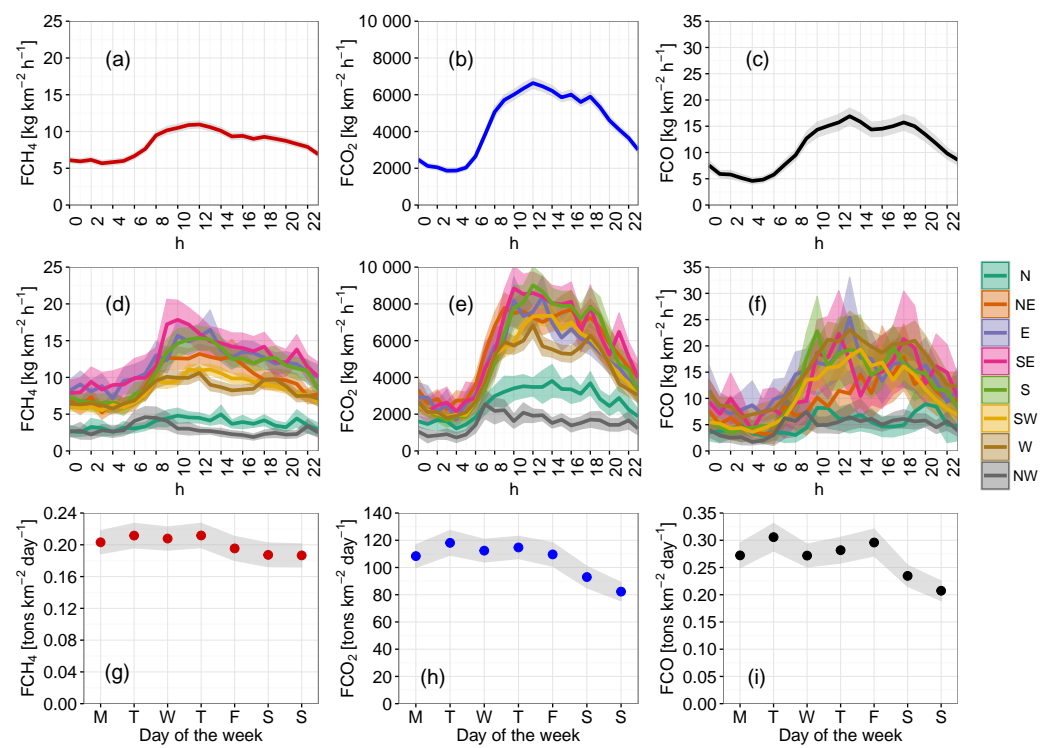

Figure 6. Fluxes of $(\mathbf{a}, \mathbf{d}, \mathbf{g})$ methane $\left(F_{\mathrm{CH} 4}\right),(\mathbf{b}, \mathbf{e}, \mathbf{h})$ carbon dioxide $\left(F_{\mathrm{CO} 2}\right)$ and $(\mathbf{c}, \mathbf{f}, \mathbf{i})$ carbon monoxide $\left(F_{\mathrm{CO}}\right)$ observed at $\mathrm{BT}$ tower with a closed-path gas analyser (from 15 September 2011 to 31 December 2014): (a-c) mean diurnal patterns with $95 \%$ confidence interval (shading), (d-f) as (a-c) but segregated into wind sectors and (g-i) by day of the week.

\section{Dependence of flux magnitude and diurnal patterns on wind sector}

Segregating emissions by wind direction reveals heterogeneous source distributions at the BT tower site with different temporal patterns (Fig. 6d-f) and source strengths (Figs. S4-S6). The lowest emissions ( \pm standard error of the mean) for all three pollutants were recorded for $\mathrm{NW}$ winds $\left(F_{\mathrm{CO}}=1.7 \pm 0.3 \mathrm{~kg} \mathrm{~km}^{-2} \mathrm{~h}^{-1}, \quad F_{\mathrm{CO} 2}=728 \pm\right.$ $\left.127 \mathrm{~kg} \mathrm{~km}^{-2} \mathrm{~h}^{-1}, F_{\mathrm{CH} 4}=1.9 \pm 0.2 \mathrm{~kg} \mathrm{~km}^{-2} \mathrm{~h}^{-1}\right)$. The highest emissions of $\mathrm{CH}_{4}$ were found in the $\mathrm{SE}$ wind sector $\left(17.8 \pm 1.3 \mathrm{~kg} \mathrm{~km}^{-2} \mathrm{~h}^{-1}\right)$, in the $\mathrm{S}$ sector for $\mathrm{CO}_{2}$ $\left(9020 \pm 515 \mathrm{~kg} \mathrm{~km}^{-2} \mathrm{~h}^{-1}\right)$ and in the $\mathrm{E}$ sector for $\mathrm{CO}$ $\left(25.4 \pm 3.9 \mathrm{~kg} \mathrm{~km}^{-2} \mathrm{~h}^{-1}\right)$. The difference in emissions between wind sectors was however only statistically significant for the $\mathrm{N}$ and $\mathrm{NW}$ wind sectors. Maxima of $F_{\mathrm{CO}}, F_{\mathrm{CO} 2}$ and $F_{\mathrm{CH} 4}$ occurred on average at around 07:00-08:00 in the NW sector. Peak emissions for $F_{\mathrm{CO} 2}$ and $F_{\mathrm{CH} 4}$ in the remaining wind sectors occurred typically between 09:00 and 12:00. The overall diurnal profile of $F_{\mathrm{CO}}$ was bimodal, except for $\mathrm{NE}$ and NW, with well-defined mid- to late-morning peaks (typically 09:00 to 12:00 GMT) followed by early evening peaks (17:00 to 19:00). $F_{\mathrm{CO}}$ and $F_{\mathrm{CO} 2}$ reached night-time minima at around 03:00 in all wind sectors whereas $F_{\mathrm{CH} 4}$ tended to plateau, except in the SE where emissions tended to increase. The onset of an early morning increase in emissions (ca. 05:00-06:00 GMT) was consistent for all wind directions for $F_{\mathrm{CO} 2}$ and $F_{\mathrm{CO}}$ but it was less clearly defined for $F_{\mathrm{CH} 4}$. In addition to diurnal trends and dependency on wind sector, emissions of all three pollutants were found to be lower on weekends (Fig. $6 \mathrm{~g}-\mathrm{i}$ ), with $\mathrm{CH}_{4}$ again showing the lowest variability (9\% reduction on weekends compared to working days for $F_{\mathrm{CH} 4}, 22 \%$ for $F_{\mathrm{CO} 2}$ and $23 \%$ for $F_{\mathrm{CO}}$ ).

\subsection{Seasonality of the measured fluxes}

For the measurement period September 2011 to December $2014, F_{\mathrm{CH} 4}, F_{\mathrm{CO} 2}$ and $F_{\mathrm{CO}}$ exhibited marked seasonal cycles with minimum emissions in summer (Fig. 7a-c). The lowest emissions of $\mathrm{CO}$ were observed in April but this is thought to be an artefact caused by relatively low temporal and spatial coverage for that month resulting from instrument downtime. Whilst not used in the discussion that follows, the April data point is included in Fig. 7c and $\mathrm{f}$ for consistency. For the months December-February, $F_{\mathrm{CO} 2}$ and $F_{\mathrm{CH} 4}$ were $4.1 \pm 0.5 \mathrm{ktons} \mathrm{km}^{-2}$ month $^{-1}$ and $7.4 \pm 0.8$ tons $\mathrm{km}^{-2}$ month $^{-1}$, respectively, and decreased to $2.7 \pm 0.3 \mathrm{ktons} \mathrm{km}^{-2}$ month $^{-1}$ (33\% reduction) and $5.8 \pm 0.4$ tons $\mathrm{km}^{-2}$ month $^{-1}$ ( $21 \%$ reduction), respectively, in summer (June-August). The difference between winter and summertime emissions of $\mathrm{CO}$ was 3-fold with $9.1 \pm 2.5$ tons $\mathrm{km}^{-2}$ month $^{-1}$ in December-February and $2.9 \pm 0.1$ tons $\mathrm{km}^{-2}$ month $^{-1}$ in June-July (due to instrument downtime, no data are available for August).

\subsubsection{Seasonal controls of fluxes of carbon monoxide and carbon dioxide}

It is well established that emissions of $\mathrm{CO}$ from petrol cars are temperature dependent, e.g. increasing by a factor of 56 at ambient temperature 0 compared to $25^{\circ} \mathrm{C}$ (Andrews et al., 2004) during the first 5-10 min following engine warmup. The strong negative linear dependence of $F_{\mathrm{CO}}$ upon air 

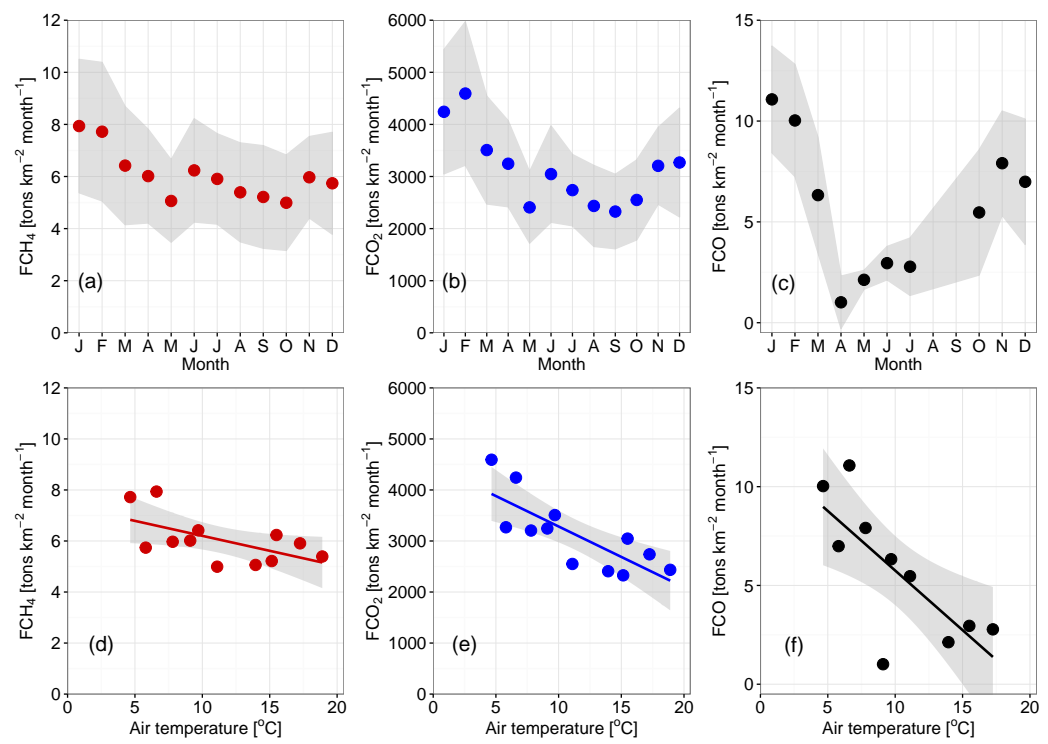

Figure 7. (a-c) Monthly averages of $F_{\mathrm{CH} 4}, F_{\mathrm{CO} 2}$ and $F_{\mathrm{CO}}$ (September 2011-December 2014); (d-f) $F_{\mathrm{CH} 4}, F_{\mathrm{CO} 2}$ and $F_{\mathrm{CO}}$ as a function of monthly mean air temperature. Solid lines are linear regressions and shaded areas are $95 \%$ confidence intervals. No $F_{\mathrm{CO}}$ measurements were available in August and September due to instrument downtime.

temperature (Fig. 7f) could thus indicate that cold starts and reduced combustion efficiency played an important role during winter. Winter time (December-February) emissions of $\mathrm{CO}$ accounted for $45 \%$ of the annual budget for this pollutant which is consistent with LAEI (LAEI, 2013) estimates of the combined natural gas and cold start contribution to annual $\mathrm{CO}$ emissions (total $32 \%$, with 26 and $6 \%$ attributed to cold starts and natural gas consumption, respectively). $F_{\mathrm{CO} 2}$ was also correlated with air temperature (Fig. 7e; $R^{2}=0.59$ ), albeit to a lesser extent than $F_{\mathrm{CO}}$, which reflected the seasonal changes in domestic and commercial natural gas usage, but may also be influenced by increased photosynthetic uptake by vegetation in the footprint during the warmer months. Anti-correlations between monthly $F_{\mathrm{CO} 2}$ and air temperature have been reported in other studies (e.g. Beijing, Liu et al., 2012; London, Ward et al., 2015). The gradient between $F_{\mathrm{CO} 2}$ and air temperature observed in this study $\left(-0.94 \mu \mathrm{mol} \mathrm{m}{ }^{-2} \mathrm{~s}^{-1}{ }^{\circ} \mathrm{C}^{-1}\right)$ falls between the values reported for the London site $\left(-1.95 \mu \mathrm{mol} \mathrm{m}^{-2} \mathrm{~s}^{-1}{ }^{\circ} \mathrm{C}^{-1}\right)$ and the Beijing site $\left(-0.34 \mu \mathrm{mol} \mathrm{m}{ }^{-2} \mathrm{~s}^{-1}{ }^{\circ} \mathrm{C}^{-1}\right)$.

The flux ratio of $\mathrm{CO}$ to $\mathrm{CO}_{2}$ is of the order of $4 \mathrm{mmol} \mathrm{mol}^{-1}$ in winter (excess $\mathrm{CO}$ due to cold starts and incomplete combustion) and $2 \mathrm{mmol} \mathrm{mol}^{-1}$ in summer despite only moderate seasonal variations in traffic loads (Fig. S7). Traffic loads at Marylebone Road, one of the busiest arteries in central London located $<1 \mathrm{~km}$ north of the BT Tower, varied by less than $5 \%$ seasonally in the period June 2012 to December 2014 (source Transport for London; Miah Parvin, personal communication, 2015). The seasonality of $F_{\mathrm{CO} 2}$ is hence likely controlled by changes in natural gas consumption and vegetation (Gioli et al., 2012; Helfter et al., 2011).
This is further supported by relatively constant ratios of $F_{\mathrm{CH} 4}$ to $F_{\mathrm{CO} 2}$ which suggests that seasonal variations in emissions were of comparable magnitude for these two gases (Fig. S7). On average over the full 3 years of the study (2012-2014), summertime $F_{\mathrm{CO} 2}$ were $30 \%$ lower than in winter (29\% in $2012,30 \%$ in 2013 and 2014). In comparison, during an earlier study at the same site covering the year 2007, the winter to summer decrement was only $20 \%$ (Helfter et al., 2011).

\subsubsection{Seasonal controls of methane emissions}

Fluxes of $\mathrm{CH}_{4}$ were $17 \%$ lower in summer than in winter (18, 12 and $20 \%$ for 2012,2013 and 2014 respectively) and the linear correlation of monthly averages with temperature was not statistically significant (Fig. $7 \mathrm{~d} ; R^{2}=0.31$, $p$ value $=0.06$ ). In contrast, the winter to summer decrease was of the order of $63 \%$ in the city of Łódź, Poland (Pawlak and Fortuniak, 2016) and the dependence of $F_{\mathrm{CH} 4}$ upon air temperature was statistically significant. The weaker correlation of $F_{\mathrm{CH} 4}$ with air temperature in London suggests that the total methane flux is due to a superposition of sources with constant and time-varying emission rates, whereas in Florence (Italy) no significant seasonality in $\mathrm{CH}_{4}$ emissions was observed (Gioli et al., 2012). They related this to a constant pressure in the gas distribution network serving Florence. However, seasonality in both $\mathrm{CH}_{4}$ concentrations and isotopic signature have been reported in the Greater London area (Lowry et al., 2001). The winter time increase above background in $\mathrm{CH}_{4}$ concentrations and the accompanying enrichment in $\delta^{13} \mathrm{C}$ were consistent with North Sea natural gas and attributed to losses of $\mathrm{CH}_{4}$ from over-pressurized pipelines in response to (or anticipation of) an increase in 
Table 1. Annual totals of carbon dioxide flux and methane flux calculated from monthly averages for the period 2012-2014. The data period September 2012-March 2013 (no ultrasonic anemometer) was gapfilled using available monthly averages obtained over the remaining measurement period. Due to insufficient temporal coverage, individual annual budgets for 2012-2014 could not be derived for the carbon monoxide flux. A composite annual emissions estimate was compiled instead which makes use of all available monthly averages of $F_{\mathrm{CO}}$ over the study period September 2011 to December 2014. Data from the London Atmospheric Emissions Inventory (LAEI; emissions for the central London boroughs of Westminster and Camden) and previous measurement campaigns are provided for comparison with the current study.

\begin{tabular}{llrrr}
\hline & Reference & $F_{\mathrm{CO} 2}\left[\mathrm{kt} \mathrm{km}^{-2}\right]$ & $F_{\mathrm{CH} 4}\left[\mathrm{t} \mathrm{km}^{-2}\right]$ & $F_{\mathrm{CO}}\left[\mathrm{t} \mathrm{km}^{-2}\right]$ \\
\hline 2012 & This study & 40.2 & 69 & - \\
2013 & This study & 40.7 & 75 & - \\
2014 & This study & 36.3 & 72 & - \\
Mean \pm SD & This study & $39.1 \pm 2.4$ & $72 \pm 3$ & 89 \\
Random uncertainty & This study & 6.5 & 12 & 16 \\
Emissions inventory (2012) & LAEI & 38.7 & 29 & 110 \\
London 2007 & Helfter et al. (2011) & 35.5 & - & - \\
London & Ward et al. (2015) & 46.6 & & $150-220$ \\
London Autumn 2007/2008 & Harrison et al. (2012) & & 66 & 106 \\
London July 2012 & O'Shea et al. (2014) & 29.0 & & \\
\hline
\end{tabular}

* Aircraft measurements.

demand and to incomplete combustion upon boiler ignition. The seasonality of $F_{\mathrm{CH} 4}$ in Łódź (Poland) was also attributed to variations in natural gas usage (Pawlak and Fortuniak, 2016). Urban $\mathrm{CH}_{4}$ emissions in Boston (USA) attributed to natural gas use also displayed a modest, albeit not statistically significant, seasonality, with lower emissions during the summer (McKain et al., 2015). An increase of total $\mathrm{CH}_{4}$ emissions in summer could indicate temperature-sensitive biogenic sources played an important role in Boston. Although individually small, fugitive post-metre emissions (i.e. in homes or work place) can make a non-negligible cumulative contribution at the city scale (Wennberg et al., 2012). Post-metre emissions are made up of time-varying (incomplete combustion upon natural gas appliance ignition and/or usage) and constant components (leaking valves and/or fittings) which contribute to both the seasonal variability and to the baseline of $\mathrm{CH}_{4}$ emissions. Finally, methane emissions from liquefied petroleum gas (LPG) vehicles, although small compared to natural gas emissions, exhibit a positive dependence upon temperature (Nam et al., 2004) and are expected to also contribute to the seasonality and diurnal variation of the total urban $\mathrm{CH}_{4}$ fluxes.

\subsection{Annual budgets of methane, carbon monoxide and carbon dioxide emissions}

Annual emissions of $\mathrm{CO}_{2}$ ranged from 36.3 to $40.7 \mathrm{ktons} \mathrm{km}^{-2} \mathrm{yr}^{-1}$ with a 3-year mean of $39.1 \pm 2.4 \mathrm{ktons} \mathrm{km}^{-2} \mathrm{yr}^{-1}$ (Table 1). These values are in good agreement with results from a previous measurement campaign at the BT tower in 2007 (35.5 ktons km-2 $\mathrm{yr}^{-1}$; Helfter et al., 2011) and London Atmospheric Emissions Inventory (LAEI) bottom-up emission estimates for the central
London boroughs of Westminster and Camden, which are the foremost spatial source areas entrained by the BT tower flux footprint. The good agreement for $\mathrm{CO}_{2}$ obtained in the present and previous studies using different instrumentation provides a benchmark for subsequent comparisons between top-down measurements and bottom-up inventory estimates. Due to insufficient temporal coverage, individual annual budgets for 2012-2014 could not be derived for CO. Instead, one single annual $\mathrm{CO}$ flux value was calculated from individual monthly averages collected in the period September 2011-December 2014 on the assumption that year-on-year variability was small. Furthermore, emissions of $\mathrm{CO}$ for August and September, when no observations were available, were estimated from a linear relation between $F_{\mathrm{CO}}$ and air temperature (Fig. 7f). The composite annual emissions estimate of $89 \pm 16 \mathrm{t} \mathrm{km}^{-2} \mathrm{yr}^{-1}$ (range taken as the random uncertainty) is consistent with the LAEI data (Table 1).

Flux ratios are less sensitive to limitations in vertical transport and provide an additional means of assessing the quality of the bottom-up emission inventories and identifying poorly represented sources. Measured flux ratios of $F_{\mathrm{CO}}$ to $F_{\mathrm{CO} 2}$ were consistent with average LAEI emission ratios (Table 2, Fig. S9). Measured flux ratios of $F_{\mathrm{CO}}$ to $F_{\mathrm{CH} 4}$ were about half the inventoried values and measured ratios of $F_{\mathrm{CH} 4}$ to $F_{\mathrm{CO} 2}$ were twice the mean LAEI values (Table 2; Fig. S8), consistent with the measured annual $\mathrm{CH}_{4}$ fluxes (3year mean $72 \pm 3 \mathrm{t} \mathrm{km}^{-2} \mathrm{yr}^{-1}$ ) being more than twice the inventory value. This indicates that some $\mathrm{CH}_{4}$ sources were either underestimated or unaccounted for by the LAEI. Of the source categories included in the LAEI and listed in Table 2 only gas leakage has the potential to increase the $\mathrm{CH}_{4} / \mathrm{CO}_{2}$ flux ratio, but an underestimation in leakage is only a possi- 
Table 2. Emission ratios from measurements and the London Atmospheric Emissions Inventory (LAEI). Measured quantities are mean, median and range of monthly emissions segregated by wind direction.

\begin{tabular}{llrrr}
\hline Emission category & Zone & $F_{\mathrm{CH} 4} / F_{\mathrm{CO} 2}$ & $F_{\mathrm{CO}} / F_{\mathrm{CO} 2}$ & $F_{\mathrm{CO}} / F_{\mathrm{CH} 4}$ \\
\hline Measured (this study): & & & & \\
Mean & & 0.0019 & 0.0018 & 0.9739 \\
Median & & 0.0019 & 0.0021 & 1.1304 \\
Minimum & & 0.0017 & 0.0004 & 0.1972 \\
Maximum & & 0.0022 & 0.0027 & 1.5951 \\
LAEI (all sources) & Central & 0.0009 & 0.0039 & 4.1023 \\
& Inner & 0.0010 & 0.0024 & 2.4546 \\
& Outer & 0.0094 & 0.0018 & 0.1965 \\
Domestic coal & Central & - & - & - \\
& Inner & 0.0020 & 0.0460 & 22.400 \\
& Outer & 0.0020 & 0.0460 & 22.414 \\
Domestic oil & Everywhere & 0.0001 & 0.0006 & 4.0000 \\
Domestic gas & Everywhere & 0.0001 & 0.0006 & 6.0375 \\
Non-domestic gas & Everywhere & 0.0001 & 0.0002 & 2.2642 \\
Boilers & Central & 0.0001 & $4 \times 10^{-5}$ & 0.3270 \\
& Inner & 0.0001 & $5 \times 10^{-5}$ & 0.3548 \\
& Outer & 0.0001 & $5 \times 10^{-5}$ & 0.3482 \\
Gas leakage & Everywhere & 26.607 & - & - \\
Non-road mobile machinery, agriculture and other & Central & 0.0002 & 0.0347 & 213.55 \\
& Inner & 0.0003 & 0.0377 & 119.75 \\
Road - all sources & Outer & 0.3525 & 0.0576 & 0.1633 \\
& Central & - & 0.0021 & - \\
& Inner & - & 0.0013 & - \\
\hline & Outer & - & 0.0013 & - \\
\hline & & & -
\end{tabular}

ble explanation if it follows the measured diurnal cycle, either due to changes in the supply pressure or in post-metre emissions. We speculate that the diurnal, seasonal and spatial variations in $F_{\mathrm{CH} 4}$, and the larger $F_{\mathrm{CH} 4} / F_{\mathrm{CO} 2}$ ratio could be due a contribution of temperature-sensitive $\mathrm{CH}_{4}$ emissions perhaps of biogenic origin (e.g. increased methanogenesis from sewerage) not included in the inventories. This could explain why the net seasonal decrease in $\mathrm{CH}_{4}$ was but half that of $\mathrm{CO}_{2}$ (Fig. 7a and b). Previously reported discrepancies of 1.5 to $>2$ between top-down and bottom-up estimates of $\mathrm{CH}_{4}$ for the South Coast Air Basin in the greater Los Angeles (USA) area have been related to emissions from landfills and other biogenic sources (Hsu et al., 2010; Wunch et al., 2009). In our study, annual methane fluxes exhibited substantial spatial variability when segregated by wind sector (Fig. 8a). Fluxes of methane in the E, S and SE sectors were ca. $30 \%$ larger than the mean annual $F_{\mathrm{CH} 4}$ estimate and exceeded the top boundary of the overall mean (taken as mean $F_{\mathrm{CH} 4}+$ maximum monthly uncertainty; Fig. 8a). In contrast, $F_{\mathrm{CH} 4}$ from the $\mathrm{N}$ and NW sectors were 40 and $30 \%$ of the mean value, respectively, and fell below the lower limit of the overall mean (taken as mean $F_{\mathrm{CH} 4}$ - maximum monthly uncertainty). This perhaps suggests more complex, spatially discrete, source distribution and composition for $\mathrm{CH}_{4}$ compared with $\mathrm{CO}_{2}$ and $\mathrm{CO}$. The linear correlation between $F_{\mathrm{CH} 4}$ and population was strong if the highest emitting wind sectors (E, S and SE) were excluded from the regression (Fig. 8b). Socio-economic temporal dynamics, such as a significant daytime influx of commuters into a business district (e.g. the City of London financial district which is located 3$4 \mathrm{~km} \mathrm{~S}-\mathrm{SE}$ of the BT tower), might contribute substantially to $\mathrm{CH}_{4}$ emissions (e.g. from sewage, natural gas); in addition, the measured $\mathrm{CH}_{4}$ emissions from such business areas might bear no correlation with the actual resident population reported here (source: London Datastore, Greater London Authority, 2016) which can be considerably smaller than the commuting workforce. Emissions of $\mathrm{CH}_{4}$ in the $\mathrm{E}$ were strongly correlated with air temperature (Table 3 ), which suggests one or more dominant seasonal source in that wind sector. Finally, neither test was statistically significant for emissions in the SE and S where the flux footprints entrain some of the most heavily urbanized areas of central London as well as part of the river Thames. Further work is needed to investigate the potential presence of additional sources of $\mathrm{CH}_{4}$ which might be prevalent in those wind sectors.

As for $\mathrm{CH}_{4}, \mathrm{CO}_{2}$ fluxes exhibited a dependence upon air temperature in the N, NE, E and W. The seasonality of the $\mathrm{CO}_{2}$ emissions was not statistically significant in the remaining wind sectors which might be due to the presence of substantial constant sources of $\mathrm{CO}_{2}$ or to the prevalence of seasonal activities which do not emit $\mathrm{CO}_{2}$ locally (e.g. more electrical heating than natural gas). However, the spatial vari- 

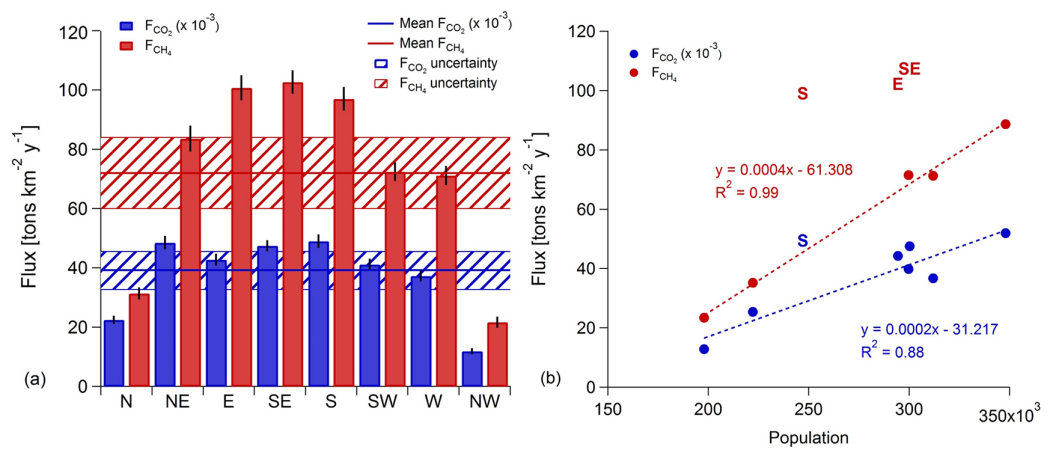

Figure 8. Annual fluxes of carbon dioxide $\left(F_{\mathrm{CO} 2}\right)$ and methane $\left(F_{\mathrm{CH} 4}\right)$ measured by eddy-covariance at the BT tower in central London as a function of (a) wind direction; solid lines are mean annual emissions (2012-2014) without wind sector segregation. Measurement uncertainty (taken as the maximum of monthly uncertainties for each gas) is denoted by a blue $\left(F_{\mathrm{CO} 2}\right)$ and red striped areas $\left(F_{\mathrm{CH} 4}\right)$. (b) Data from plot (a) as a function of population within each wind sector-specific flux footprint area. The spatial extent of the footprint for each wind sector was derived from footprint statistics (Fig. 3) with the approximation that the typical extent was of the order of $10 \mathrm{~km}$ for NE-SW and $15 \mathrm{~km}$ for W-N. Population data (source: London Datastore, Greater London Authority, 2016) are on a ward basis (i.e. sub-borough administrative unit). Linear regression (dashed lines), with exclusion of $\mathrm{S}$ sector data point for $F_{\mathrm{CO} 2}, \mathrm{E}, \mathrm{S}$ and $\mathrm{SE}$ for $F_{\mathrm{CH} 4}$ (identified by their wind sector abbreviations). NB: $F_{\mathrm{CO} 2}$ and associated uncertainty are divided by 1000 to aid visualization.

Table 3. Goodness of fit of the linear regression between wind sector-segregated monthly methane fluxes $\left(F_{\mathrm{CH} 4}\right)$, carbon dioxide fluxes $\left(F_{\mathrm{CO} 2}\right)$ and monthly mean air temperature $\left(T_{\text {air }}\right)$. The superscripts $(-)$ and $(+)$ denote the sign of slope for each linear regression. $p$ values in bold denote statistical significance.

\begin{tabular}{lrrrrrrrr}
\hline$R^{2}$ & $\mathrm{~N}$ & $\mathrm{NE}$ & $\mathrm{E}$ & $\mathrm{SE}$ & $\mathrm{S}$ & $\mathrm{SW}$ & $\mathrm{W}$ & $\mathrm{NW}$ \\
\hline$F_{\text {CH4 }}$ vs. $T_{\text {air }}$ & $0.55^{(-)}$ & $0.43^{(-)}$ & $0.73^{(-)}$ & $0.08^{(-)}$ & $0.04^{(-)}$ & $0.05^{(-)}$ & $0.60^{(-)}$ & $0.21^{(-)}$ \\
$p$ value & $\mathbf{0 . 0 0 6 0}$ & $\mathbf{0 . 0 1 9 7}$ & $\mathbf{0 . 0 0 0 4}$ & 0.3627 & 0.5150 & 0.4790 & $\mathbf{0 . 0 0 3 3}$ & 0.1367 \\
$F_{\text {CO2 vs. } T_{\text {air }}}$ & $\mathbf{0 . 5 1}(-)$ & $\mathbf{0 . 6 9}{ }^{(-)}$ & $\mathbf{0 . 8 0}$ & $0.19^{(-)}$ & $0.18^{(-)}$ & $0.27^{(-)}$ & $\mathbf{0 . 6 0}(-)$ & $0.34^{(-)}$ \\
$p$ value & $\mathbf{0 . 0 2 0 3}$ & $\mathbf{0 . 0 0 2 1}$ & $\mathbf{0 . 0 0 0 3}$ & 0.1496 & 0.1984 & 0.1650 & $\mathbf{0 . 0 0 8 1}$ & 0.0776 \\
\hline
\end{tabular}

ability of $F_{\mathrm{CO} 2}$ was well-captured by differences in population in the respective flux footprints of all wind sectors, except S (Fig. 8b).

\section{Conclusions}

This study presents the results of more than 3 years of continuous long-term eddy-covariance observations of fluxes of $\mathrm{CO}, \mathrm{CO}_{2}$ and $\mathrm{CH}_{4}$ at an elevated measurement site (BT tower, $190 \mathrm{~m}$ a.g.l.) in central London, UK. This unique vantage point, combined with the length of the study, allowed for the spatial and temporal emission dynamics to be analysed in detail. The main conclusions are that all three trace gases exhibited diurnal cycles consistent with anthropogenic activities (traffic, natural gas use) and underwent marked seasonal dynamics, with reduced emissions in the summer.

Emissions of $\mathrm{CO}$ were strongly correlated with air temperature which is thought to be due to cold starts and reduced fuel combustion efficiency by the London fleet during the winter. Winter time emissions of $\mathrm{CO}$ accounted for $45 \%$ of the annual budget. Emissions of $\mathrm{CO}_{2}$ were also correlated to air temperature and were $33 \%$ larger in winter than in summer. $\mathrm{CO}_{2}$ emissions were predominantly controlled by the seasonal increase in natural gas consumption, although vegetation uptake would also have lowered $\mathrm{CO}_{2}$ fluxes in summer. $\mathrm{CH}_{4}$ fluxes averaged over all wind sectors decreased by $21 \%$ between winter and summer but unlike $\mathrm{CO}$ and $\mathrm{CO}_{2}$, the correlation with air temperature was not statistically significant. When segregated by wind sector, $\mathrm{CH}_{4}$ fluxes in the $\mathrm{E}$ and $\mathrm{W}$ were strongly correlated with air temperature suggestive of sources with highly seasonal emission rates, possibly leaks from the natural gas distribution network or emissions from sewage. Furthermore, $\mathrm{CO}_{2}$ and $\mathrm{CH}_{4}$ fluxes were positively correlated with population density in all wind sectors except $\mathrm{S}$ for $F_{\mathrm{CO} 2}$ and $\mathrm{S}, \mathrm{SE}$ and $\mathrm{E}$ for $F_{\mathrm{CH} 4}$. This indicates heterogeneous source distributions and/or densities with temporal dynamics which differ from the other wind sectors.

Measured annual emissions of $\mathrm{CO}_{2}\left(39 \mathrm{ktons} \mathrm{km}^{-2}\right)$ were in good agreement with bottom-up estimates from the London Atmospheric Emissions Inventory (LAEI). $\mathrm{As}^{\mathrm{CO}_{2}}$ is the most accurately represented of the three compounds in emission inventories, this provides confidence in the flux measurements. Similarly, the measured annual budget for $\mathrm{CO}$ (89 tons $\mathrm{km}^{-2}$ ) was consistent with LAEI values which confirms that the spatial distribution of the sources of this pollutant is well captured by the inventory. However, the measured 
annual $\mathrm{CH}_{4}$ emissions ( 72 tons $\mathrm{km}^{-2}$ ) were more than double the LAEI value suggesting that sources are not as wellcharacterized by the inventory. In particular, we hypothesize that the shortfall in inventoried $\mathrm{CH}_{4}$ emissions can be explained by the existence of temperature-dependent sources related to natural gas usage and perhaps also of biogenic origin (e.g. sewage).

\section{Data availability}

The half-hourly data for the BT tower (site name UK-LBT) can be obtained from the European Flux Database (http:// www.europe-fluxdata.eu/ingos).

\section{The Supplement related to this article is available online at doi:10.5194/acp-16-10543-2016-supplement.}

Acknowledgements. The authors acknowledge a succession of projects for funding this research (NERC-funded projects ClearfLo (H003231/1), GAUGE (NE/K002279/1)) as well as support by NERC National Capability funding, the EU FP7 Infrastructure Project InGOS project (284274), the EU FP7 Grant BRIDGE (211345), and King's College London.

The authors also acknowledge British Telecom (BT) for granting use of the tall tower for research purposes. In particular, we are grateful to Karen Ahern for arranging work permits and facilitating access to the site. Thank you also to aerial riggers Robert Semon, Wayne Loeber and Mark West for help with the installation and maintenance of the rooftop instruments. We are grateful to BT security and facilities staff for their continued support and assistance with day-to-day logistics and to Neil Mullinger (Centre for Ecology and Hydrology) for help with instrument maintenance and visits to the site. Supporting the KCL observations, we thank Arnold Moene at Wageningen University for providing the ECpack software; all staff and students at KCL and University of Reading (Grimmond group) who contributed to the data collection; KCL Directorate of Estates and Facilities for giving us the opportunity to operate the various measurement sites.

Edited by: M. Heimann

Reviewed by: three anonymous referees

\section{References}

ARB (Air Resources Board): California Environment Protection Agency, available at: http://www.arb.ca.gov/ei/ei.htm, last access: 1 March 2016.

Andrews, G. E., Zhu, G., Li, H., Simpson, A., Wylie, J. A., Bell, M., and Tate, J.: The effect of ambient temperature on cold start urban traffic emissions for a real world SI car, Proceedings of SAE 2004 Powertrain \& Fluid Systems Conference and Exhibition Tampa, FL, USA, 2004.
Aubinet, M., Grelle, A., Ibrom, A., Rannik, U., Moncrieff, J., Foken, T., Kowalski, A. S., Martin, P. H., Berbigier, P., Bernhofer, C., Clement, R., Elbers, J., Granier, A., Grunwald, T., Morgenstern, K., Pilegaard, K., Rebmann, C., Snijders, W., Valentini, R., and Vesala, T.: Estimates of the annual net carbon and water exchange of forests: The EUROFLUX methodology, Adv. Ecol. Res., 30, 113-175, 2000.

Baldocchi, D.: Breathing of the terrestrial biosphere: Lessons learned from a global network of carbon dioxide flux measurement systems, Aust. J. Bot., 56, 1-26, doi:10.1071/bt07151, 2008.

Baldocchi, D., Falge, E., Gu, L. H., Olson, R., Hollinger, D., Running, S., Anthoni, P., Bernhofer, C., Davis, K., Evans, R., Fuentes, J., Goldstein, A., Katul, G., Law, B., Lee, X. H., Malhi, Y., Meyers, T., Munger, W., Oechel, W., U, K. T. P., Pilegaard, K., Schmid, H. P., Valentini, R., Verma, S., Vesala, T., Wilson, K., and Wofsy, S.: Fluxnet: A new tool to study the temporal and spatial variability of ecosystem-scale carbon dioxide, water vapor, and energy flux densities, B. Am. Meteorol. Soc., 82, 2415-2434, doi:10.1175/1520-0477(2001)082<2415:fantts>2.3.co;2, 2001.

Barlow, J. F., Dunbar, T. M., Nemitz, E. G., Wood, C. R., Gallagher, M. W., Davies, F., O'Connor, E., and Harrison, R. M.: Boundary layer dynamics over London, UK, as observed using Doppler lidar during REPARTEE-II, Atmos. Chem. Phys., 11, 2111-2125, doi:10.5194/acp-11-2111-2011, 2011.

Barlow, J. F., Halios, C. H., Lane, S. E., and Wood, C. R.: Observations of urban boundary layer structure during a strong urban heat island event, Environ. Fluid Mech., 15, 373-398, doi:10.1007/s10652-014-9335-6, 2015.

Bjorkegren, A. B., Grimmond, C. S. B., Kotthaus, S., and Malamud, B. D.: $\mathrm{CO}_{2}$ emission estimation in the urban environment: Measurement of the $\mathrm{CO}_{2}$ storage term, Atmos. Environ., 122, 775-790, doi:10.1016/j.atmosenv.2015.10.012, 2015.

Bohnenstengel, S. I., Belcher, S. E., Aiken, A., Allan, J. D., Allen, G., Bacak, A., Bannan, T. J., Barlow, J. F., Beddows, D. C. S., Bloss, W. J., Booth, A. M., Chemel, C., Coceal, O., Di Marco, C. F., Dubey, M. K., Faloon, K. H., Fleming, Z. L., Furger, M., Gietl, J. K., Graves, R. R., Green, D. C., Grimmond, C. S. B., Halios, C. H., Hamilton, J. F., Harrison, R. M., Heal, M. R., Heard, D. E., Helfter, C., Herndon, S. C., Holmes, R. E., Hopkins, J. R., Jones, A. M., Kelly, F. J., Kotthaus, S., Langford, B., Lee, J. D., Leigh, R. J., Lewis, A. C., Lidster, R. T., LopezHilfiker, F. D., McQuaid, J. B., Mohr, C., Monks, P. S., Nemitz, E., Ng, N. L., Percival, C. J., Prevot, A. S. H., Ricketts, H. M. A., Sokhi, R., Stone, D., Thornton, J. A., Tremper, A. H., Valach, A. C., Visser, S., Whalley, L. K., Williams, L. R., Xu, L., Young, D. E., and Zotter, P.: Meteorology, air quality, and health in London the ClearfLo project, B. Am. Meteorol. Soc., 96, 779-804, doi:10.1175/bams-d-12-00245.1, 2015.

Cambaliza, M. O. L., Shepson, P. B., Bogner, J., Caulton, D. R., Stirm, B., Sweeney, C., Montzka, S. A., Gurney, K. R., Spokas, K., Salmon, O. E., Lavoie, T. N., Hendricks, A., Mays, K., Turnbull, J., Miller, B. R., Lauvaux, T., Davis, K., Karion, A., Moser, B., Miller, C., Obermeyer, C., Whetstone, J., Prasad, K., Miles, N., and Richardson, S.: Quantification and source apportionment of the methane emission flux from the city of indianapolis, Elementa Science of the Anthropocene, 3, 000037, doi:10.12952/journal.elementa.000037, 2015. 
Carslaw, D. C. and Ropkins, K.: openair - an R package for air quality data analysis, Environ. Model. Softw., 27-28, 52-61, 2012.

Carslaw, D. C. and Ropkins, K.: openair: Open-source tools for the analysis of air pollution data, $\mathrm{R}$ package version 1.7-3, available at: http://CRAN.R-project.org/package=openair, last access: 1 March 2016.

Christen, A., Coops, N. C., Crawford, B. R., Kellett, R., Liss, K. N., Olchovski, I., Tooke, T. R., van der Laan, M., and Voogt, J. A.: Validation of modeled carbon-dioxide emissions from an urban neighborhood with direct eddycovariance measurements, Atmos. Environ., 45, 6057-6069, doi:10.1016/j.atmosenv.2011.07.040, 2011.

Crosson, E. R.: A cavity ring-down analyzer for measuring atmospheric levels of methane, carbon dioxide, and water vapor, Appl. Phys. B, 92, 403-408, doi:10.1007/s00340-008-3135-y, 2008.

Evans, S.: 3D cities and numerical weather prediction models: An overview of the methods used in the LUCID project, available at: http://discovery.ucl.ac.uk/17404/ (last access: 17 August 2016) UCL Working Paper Series, 2009.

Fiddler, M. N., Begashaw, I., Mickens, M. A., Collingwood, M. S., Assefa, Z., and Bililign, S.: Laser spectroscopy for atmospheric and environmental sensing, Sensors, 9, 10447-10512, doi:10.3390/s91210447, 2009.

Finkelstein, P. L. and Sims, P. F.: Sampling error in eddy correlation flux measurements, J. Geophys. Res.-Atmos., 106, 3503-3509, doi:10.1029/2000jd900731, 2001.

Foken, T.: Micrometeorology, Springer-Verlag Berlin Heidelberg, 308 pp., 2008.

Foken, T. and Wichura, B.: Tools for quality assessment of surfacebased flux measurements, Agr. Forest Meteorol., 78, 83-105, doi:10.1016/0168-1923(95)02248-1, 1996.

Foken, T., Gödecke, M., Mauder, M., Mahrt, L., Amiro, B., and Munger, W.: Post-field data quality control, in: Handbook of micrometeorology, edited by: Lee, X., Kluwer Academic Publishers, 2004.

Gioli, B., Toscano, P., Lugato, E., Matese, A., Miglietta, F., Zaldei, A., and Vaccari, F. P.: Methane and carbon dioxide fluxes and source partitioning in urban areas: The case study of Florence, Italy, Environ. Pollut., 164, 125-131, doi:10.1016/j.envpol.2012.01.019, 2012.

Greater London Authority: London Datastore, available at: http:// data.london.gov.uk/, last access: 1 March 2016.

Grimmond, C. S. B. and Christen, A.: Flux measurements in urban ecosystems, in: FluxLetter, The newsletter of FLUXNET, 1, available at: https://fluxnet.ornl.gov/sites/default/ files/FluxLetter_Vol5_no1.pdf (last access: 17 August 2016), 2012.

Halios, C. H. and Barlow, J. F.: Observations of the morning development of the urban boundary layer over London, UK, taken during the ACTUAL project, Bound.-Lay. Meteorol., under review, 2016.

Harrison, R. M., Dall'Osto, M., Beddows, D. C. S., Thorpe, A. J., Bloss, W. J., Allan, J. D., Coe, H., Dorsey, J. R., Gallagher, M., Martin, C., Whitehead, J., Williams, P. I., Jones, R. L., Langridge, J. M., Benton, A. K., Ball, S. M., Langford, B., Hewitt, C. N., Davison, B., Martin, D., Petersson, K. F., Henshaw, S. J., White, I. R., Shallcross, D. E., Barlow, J. F., Dunbar, T., Davies, F., Nemitz, E., Phillips, G. J., Helfter, C., Di Marco, C. F., and Smith, S.: Atmospheric chemistry and physics in the atmosphere of a developed megacity (London): an overview of the REPARTEE experiment and its conclusions, Atmos. Chem. Phys., 12, 3065-3114, doi:10.5194/acp-12-3065-2012, 2012.

Helfter, C., Famulari, D., Phillips, G. J., Barlow, J. F., Wood, C. R., Grimmond, C. S. B., and Nemitz, E.: Controls of carbon dioxide concentrations and fluxes above central London, Atmos. Chem. Phys., 11, 1913-1928, doi:10.5194/acp-11-1913-2011, 2011.

Hsu, Y.-K., VanCuren, T., Park, S., Jakober, C., Herner, J., FitzGibbon, M., Blake, D. R., and Parrish, D. D.: Methane emissions inventory verification in Southern California, Atmos. Environ., 44, 1-7, doi:10.1016/j.atmosenv.2009.10.002, 2010.

International Energy Agency: World energy outlook, available at: http://www.iea.org/publications/freepublications/publication/ world-energy-outlook-2012.html (last access: 1 March 2016), 2012.

IPCC (International Panel on Climate Change): IPCC fifth assessment report: Climate change 2013, available at: https://www. ipcc.ch/report/ar5/wg1/ (last access: 17 August 2016), 2013.

Järvi, L., Nordbo, A., Junninen, H., Riikonen, A., Moilanen, J., Nikinmaa, E., and Vesala, T.: Seasonal and annual variation of carbon dioxide surface fluxes in Helsinki, Finland, in 2006-2010, Atmos. Chem. Phys., 12, 8475-8489, doi:10.5194/acp-12-84752012, 2012.

Kormann, R. and Meixner, F. X.: An analytical footprint model for non-neutral stratification, Bound.-Lay. Meteorol., 99, 207-224, doi:10.1023/a:1018991015119, 2001.

Kotthaus, S. and Grimmond, C. S. B.: Energy exchange in a dense urban environment - part II: Impact of spatial heterogeneity of the surface, Urban Climate, 10, Part 2, 281-307, doi:10.1016/j.uclim.2013.10.001, 2014a.

Kotthaus, S. and Grimmond, C. S. B.: Energy exchange in a dense urban environment - part I: Temporal variability of long-term observations in central London, Urban Climate, 10, Part 2, 261280, doi:10.1016/j.uclim.2013.10.002, 2014b.

LAEI (London Atmospheric Emissions Inventory): London Datastore, available at: http://data.london.gov.uk/dataset/ london-atmospheric-emissions-inventory-2013 (last access: 1 March 2016), 2013.

Langford, B., Nemitz, E., House, E., Phillips, G. J., Famulari, D., Davison, B., Hopkins, J. R., Lewis, A. C., and Hewitt, C. N.: Fluxes and concentrations of volatile organic compounds above central London, UK, Atmos. Chem. Phys., 10, 627-645, doi:10.5194/acp-10-627-2010, 2010.

Liu, H. Z., Feng, J. W., Järvi, L., and Vesala, T.: Four-year (20062009) eddy covariance measurements of $\mathrm{CO}_{2}$ flux over an urban area in Beijing, Atmos. Chem. Phys., 12, 7881-7892, doi:10.5194/acp-12-7881-2012, 2012.

Lowry, D., Holmes, C. W., Rata, N. D., O'Brien, P., and Nisbet, E. G.: London methane emissions: Use of diurnal changes in concentration and delta $\mathrm{C}-13$ to identify urban sources and verify inventories, J. Geophys. Res.-Atmos., 106, 7427-7448, doi:10.1029/2000jd900601, 2001.

Mayor of London Office: London population confirmed at record high, available at: https://www.london.gov.uk/press-releases/ mayoral/london-population-confirmed-at-record-high (last access: 17 August 2016), 2015.

McKain, K. K., Down, A., Raciti, S. M., Budney, J., Hutyra, L. R., Floerchinger, C., Herndon, S. C., Nehrkorn, T., Zahniser, M. S., Jackson, R. B., Phillips, N., and Wofsy, S. C.: Methane emis- 
sions from natural gas infrastructure and use in the urban region of Boston, Massachusetts, P. Natl. Acad. Sci. USA, 112, 19411946, doi:10.1073/pnas.1416261112, 2015.

Moncrieff, J., Clement, R., Finnigan, J., and Meyers, T.: Averaging, detrending and filtering of eddy covariance time series, in: Handbook of Micrometeorology, edited by: Lee, X., Kluwer Academic Publishers, 2004.

Nam, E. K., Jensen, T. E., and Wallington, T. J.: Methane emissions from vehicles, Environ. Sci. Technol., 38, 2005-2010, doi:10.1021/es034837g, 2004.

O'Shea, S. J., Allen, G., Fleming, Z. L., Bauguitte, S. J. B., Percival, C. J., Gallagher, M. W., Lee, J., Helfter, C., and Nemitz, E.: Area fluxes of carbon dioxide, methane, and carbon monoxide derived from airborne measurements around greater London: A case study during summer 2012, J. Geophys. Res.-Atmos., 119, 4940-4952, doi:10.1002/2013jd021269, 2014.

Pawlak, W. and Fortuniak, K.: Eddy covariance measurements of the net turbulent methane flux in the city centre - results of 2-year campaign in Lódz, Poland, Atmos. Chem. Phys., 16, 8281-8294, doi:10.5194/acp-16-8281-2016, 2016.

Pawlak, W., Fortuniak, K., and Siedlecki, M.: Carbon dioxide flux in the centre of Łódź, Poland - analysis of a 2-year eddy covariance measurement data set, Int. J. Climatol., 31, 232-243, doi:10.1002/joc.2247, 2011.

Peltola, O., Hensen, A., Helfter, C., Belelli Marchesini, L., Bosveld, F. C., van den Bulk, W. C. M., Elbers, J. A., Haapanala, S., Holst, J., Laurila, T., Lindroth, A., Nemitz, E., Röckmann, T., Vermeulen, A. T., and Mammarella, I.: Evaluating the performance of commonly used gas analysers for methane eddy covariance flux measurements: the InGOS inter-comparison field experiment, Biogeosciences, 11, 3163-3186, doi:10.5194/bg-113163-2014, 2014.
United Nations: World urbanization prospects, available at: http: //esa.un.org/unpd/wup/highlights/wup2014-highlights.pdf (last access: 1 March 2016), 2014.

Ward, H. C., Kotthaus, S., Grimmond, C. S. B., Bjorkegren, A., Wilkinson, M., Morrison, W. T. J., Evans, J. G., Morison, J. I. L., and Iamarino, M.: Effects of urban density on carbon dioxide exchanges: Observations of dense urban, suburban and woodland areas of southern England, Environ. Pollut., 198, 186-200, doi:10.1016/j.envpol.2014.12.031, 2015.

Wennberg, P. O., Mui, W., Wunch, D., Kort, E. A., Blake, D. R., Atlas, E. L., Santoni, G. W., Wofsy, S. C., Diskin, G. S., Jeong, S., and Fischer, M. L.: On the sources of methane to the Los Angeles atmosphere, Environ. Sci. Technol., 46, 9282-9289, doi:10.1021/es301138y, 2012.

Wood, C. R., Lacser, A., Barlow, J. F., Padhra, A., Belcher, S. E. Nemitz, E., Helfter, C., Famulari, D., and Grimmond, C. S. B.: Turbulent flow at $190 \mathrm{~m}$ height above London during 20062008: A climatology and the applicability of similarity theory, Bound.-Lay. Meteorol., 137, 77-96, doi:10.1007/s10546-0109516-x, 2010.

Wunch, D., Wennberg, P. O., Toon, G. C., Keppel-Aleks, G., and Yavin, Y. G.: Emissions of greenhouse gases from a North American megacity, Geophys. Res. Lett., 36, L15810, doi:10.1029/2009g1039825, 2009.

Zazzeri, G., Lowry, D., Fisher, R. E., France, J. L., Lanoiselle, M., and Nisbet, E. G.: Plume mapping and isotopic characterisation of anthropogenic methane sources, Atmos. Environ., 110, 151162, doi:10.1016/j.atmosenv.2015.03.029, 2015. 